\title{
Scholars and Literati at the University of Parma (1412-1800)
}

\author{
Cecilia Rolla Mara Vitale \\ IRES/LIDAM, UCLouvain
}

This note is a summary description of the set of scholars and literati who were members or associates of the University of Parma from its inception in 1412 to the eve of the Industrial Revolution (1800).

\section{The UnIVERSITY}

The official date of the foundation of the University of Parma is 1412 (Frijhoff 1996), when the Marquis Nicolo' d'Este received permission from the Pope to open the University. Before this date, there had been some attempts to create a university, but without lasting success (Mariotti 1888). After its foundation, periods of instability followed for the university. In 1540, the first Jesuits began to settle in the city. Over time, they gained great consideration from the population and from Duke Ranuccio I, who decided to turn to them when he took the first steps to reopen a university in Parma. After reaching an agreement in 1599, the organization of the university was decided: the Jesuits would teach theology, philosophy, humanities, and mathematics, and they would autonomously choose the professors among the members of their order. On the other hand, the duke himself and the commune would be responsible for appointing the professors in law and medicine. This agreement resulted in the creation of a "civic-Jesuit" university (Grendler 2017), a novelty in Italy. Because of the plague of 1630, the number of Jesuits at the university decreased. The collaboration between secular and Jesuit professors at the university came to an end in 1768, when the Duke of Parma, Ferdinand, decided to ban the Jesuit order from Parma and Piacenza. Even if the Jesuits were subsequently allowed to return, they were never allowed to teach at the University of Parma again.

\section{SOURCES}

The main source used was the book "I professori dell'Università di Parma attraverso i secoli. Note indicative bio-bibliografiche" by Fortunato Rizzi (1953). To complete the information, we used the "Dizionario biografico dei Parmigiani più illustri nelle Scienze, nelle Lettere e nelle Arti" by Giovanni Battista Janelli (1876). Grendler's book "The Universities of the Italian Renaissance" (2002) provided additional data on the professors and a comprehensive view of the history of the institution and the role of the Jesuit order. For the Jesuit professors, we used the work "Bibliothèque de la Compagnie de Jésus" by Carlos Sommervogel (1890), and the "Jesuit Science Network," a digital prosopography of the members of the Society of Jesus, created by Mrozik Dagmar in 2016. Finally, we used the dictionaries of Istituto dell'Enciclopedia Italiana (1929), in particular the online section "Dizionario Biografico degli Italiani" for further information on the activity of the members of the University of Parma and their biographies.

\section{SOME STATISTICS}

Table 1 shows some descriptive statistics. There are 395 scholars and literati. The sources used mention professors between the years 1000 and 1412, the official date of foundation. However, we 
know that at this time there was no studium generale, but rather schools of law and the arts. The year of birth is known for $39 \%$. The mean age at appointment is 36.1 years. Average life expectancy at 30 is 71.2 years, a very high value, in line with other Italian universities with a strong Jesuit presence considered thus far (Fermo and Roma) (Di Caprio and Vitale 2021; De la Croix and Karioun 2021). The birth place is known for $75.9 \%$ of individuals. The median distance between the place of birth and the university is $20 \mathrm{~km}$, confirming the local nature of this university. Finally, $11.9 \%$, of scholars have a Wikipedia page (in some language), while many of them (31.4\%) have left a footprint in the catalogues of the libraries of the world, Worldcat, either by having published some work, or by having been the subject of published books and articles.

\begin{tabular}{|c|c|c|c|c|c|c|}
\hline \multicolumn{2}{|c|}{ Period } & \multirow{2}{*}{$\begin{array}{l}\text { nb. } \\
\text { obs }\end{array}$} & \multirow{2}{*}{$\begin{array}{l}\text { \% birth year } \\
\text { known }\end{array}$} & \multirow{2}{*}{$\begin{array}{l}\text { mean age } \\
\text { at appoint. }\end{array}$} & \multirow{2}{*}{$\begin{array}{l}\text { mean age } \\
\text { at death }\end{array}$} & \multirow{2}{*}{$\begin{array}{l}\text { life exp. } \\
\text { at } 30\end{array}$} \\
\hline Start & End & & & & & \\
\hline 1000 & 1199 & 6 & 33.3 & 27 & 66 & 67 \\
\hline 1200 & 1347 & 16 & 18.8 & 22 & 66.5 & 82 \\
\hline 1348 & 1449 & 24 & 45.8 & 45.5 & 66.9 & 63.6 \\
\hline 1450 & 1526 & 11 & 45.5 & 36 & 63 & 69.5 \\
\hline 1527 & 1617 & 78 & 34.6 & 40.7 & 66.7 & 61.8 \\
\hline 1618 & 1685 & 113 & 15.9 & 37.9 & 67.9 & 67.9 \\
\hline 1686 & 1733 & 50 & 30 & 29.6 & 73.9 & 76.8 \\
\hline 1734 & 1800 & 97 & 75.3 & 34.7 & 68.6 & 71.5 \\
\hline \multirow[t]{3}{*}{1000} & 1800 & 395 & 39 & 36.1 & $\overline{68 . \overline{4}}$ & 71.2 \\
\hline & & & $\%$ birth place & median distance & $\%$ with & $\%$ with \\
\hline & & & known & birth-institution & Wikipedia & Worldcat \\
\hline 1000 & 1199 & & 66.7 & 0 & 33.3 & 33.3 \\
\hline 1200 & 1347 & & 50 & 0 & 25 & 37.5 \\
\hline 1348 & 1449 & & 79.2 & 88 & 37.5 & 37.5 \\
\hline 1450 & 1526 & & 81.8 & 0 & 36.4 & 54.5 \\
\hline 1527 & 1617 & & 87.2 & 52 & 11.5 & 30.8 \\
\hline 1618 & 1685 & & 61.9 & 38 & 4.4 & 18.6 \\
\hline 1686 & 1733 & & 78 & 0 & 2 & 24 \\
\hline 1734 & 1800 & & 85.6 & 27 & 13.4 & 45.4 \\
\hline 1000 & 1800 & & $\overline{7} \overline{5} . \overline{9}$ & 20 & 11.9 & 31.4 \\
\hline
\end{tabular}

Table 1: Summary statistics by period

\section{FIELDS}

Figure 1 shows the relative importance of fields, broadly defined. There is an equilibrium between the fields prominently taught by Jesuits (theology, humanities, and mathematics) on the one hand, and law and medicine on the other hand, fields that were traditionally outside the Jesuits' domain.

\section{Place of Birth}

Figure 2 is a plot of the places of birth of University of Parma scholars. The members of the university were predominantly from Parma or from Northern and Central Italy.

\section{HUMAN CAPITAL OF SCHOLARS AND LITERATI}

For each person in the database, we compute a heuristic human capital index, identified by combining information from Worldcat and Wikipedia using principal component analysis. The details are given in any issue of RETE in volumes 1-5. Figure 3 shows the names of all the scholars with a 


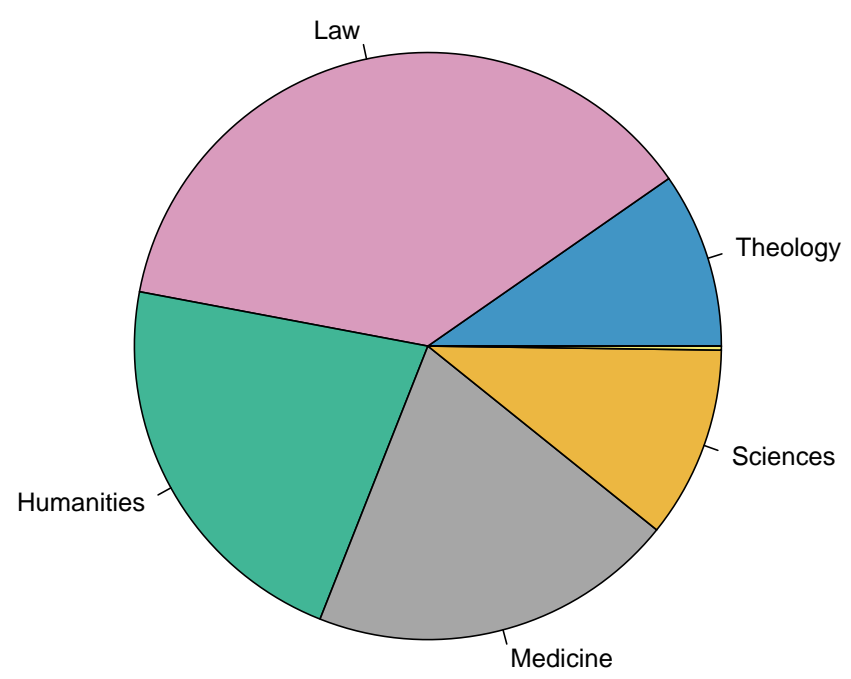

Figure 1: Broad fields at the University of Parma

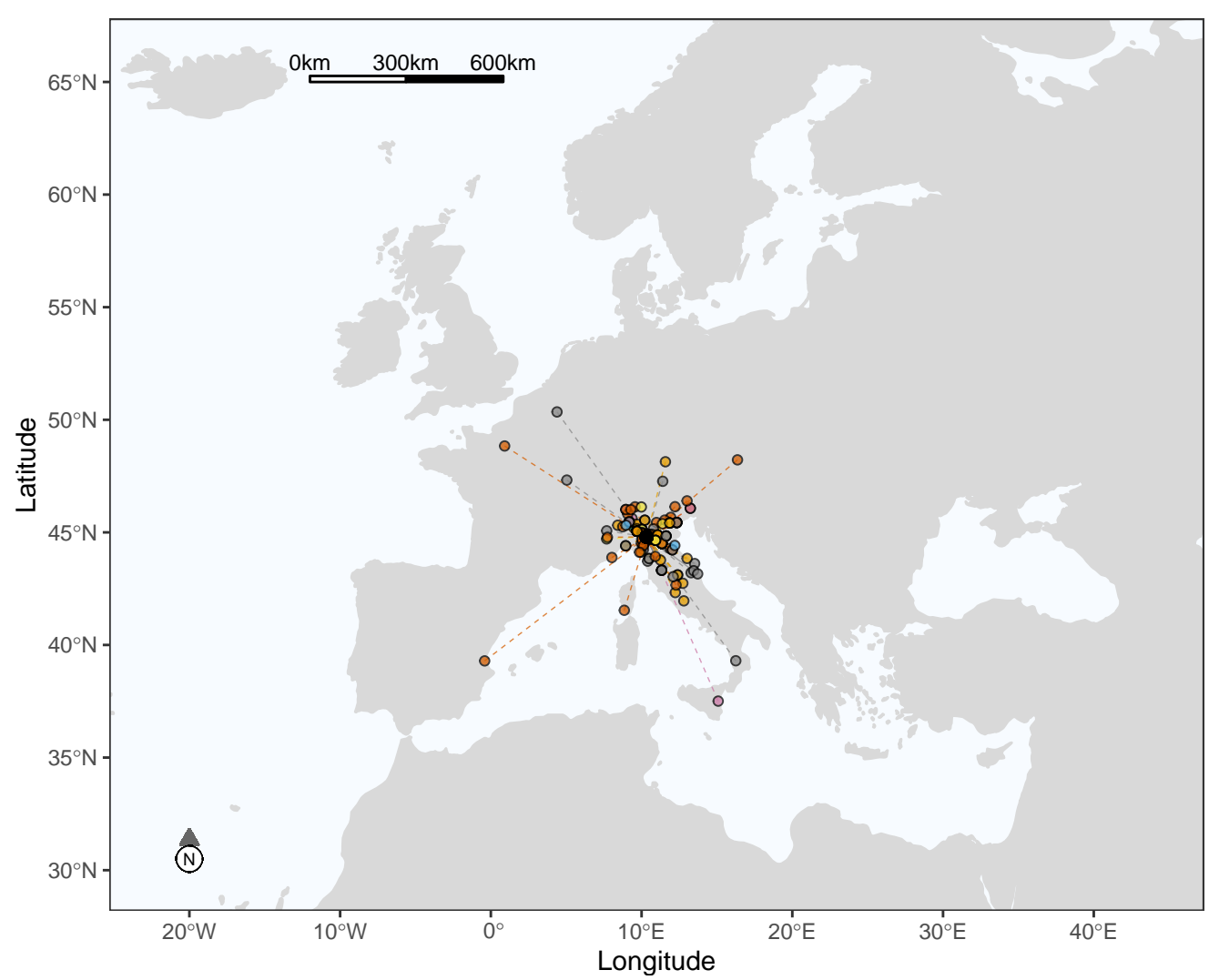

Figure 2: Places of birth of the scholars at the University of Parma 
positive human capital index. The vertical green lines (rug plot) show the distribution of all scholars, including the obscure ones, over time. The final establishment of the University of Parma at the beginning of the 17th century is clearly observable from the figure, as there is a significant increase in the membership from this date on. The orange line plots the notability of the institution. In the middle of the seventeenth century, the University of Parma reached its highest index of notability.

\section{TOP 5 SCHOLARS}

We now provide a brief overview of the five resident professors with the highest human capital index.

Pier Damiani (Ravenna c. 1007 - Faenza 1072) was a monk and cardinal, proclaimed a saint by the Catholic Church in 1828. He was a renowned theologian who produced important writings in the fields of liturgy, moral, and theology. After his studies in theology and law in Faenza and Parma, he became a teacher for a short period and then took the orders, becoming a Benedictine monk.

Giovanni Battista Riccioli (Ferrara c. 1598 - Bologna 1671) was a Jesuit, astronomer, and geographer. He taught at several schools of the Society of Jesus. In Parma, he taught logic, physics, and metaphysics. A proponent of geocentrism, he entered the astronomical debate by rejecting the three main systems that were used at the time (Ptolemaic, Copernican, and Tychonic) and developing his own. In his main work published in 1651, Almagestum novum, astronomiam veterem novamque complectens, Riccioli supports his thesis by giving 126 arguments for and against the Copernican hypothesis (49 in favor, 77 against) and hypothesized a new cosmological model to explain the irregularity of the Moon's motion. His hypothesis states that the Sun, the Moon, Jupiter, and Saturn rotate around the Earth, while Mercury, Venus, and Mars are satellites of the Sun. In this work, he also drew a lunar map, assigning names to the lunar craters that are still in use. All the major astronomers who preceded him had a crater dedicated by him.

Filippo Beroaldi (senior) (Bologna c.1453 - Bologna 1505) was a professor of rhetoric and poetry in Bologna, Parma, and Paris. He is remembered for having commented on numerous Latin authors. His works were published in the most important learning centers of the time, giving him considerable fame throughout Europe. Pico della Mirandola called him a living library.

Daniel Bartoli (Ferarra c. 1608 - Rome 1685) was a Jesuit, historian, and writer. He entered the Society of Jesus at the age of fifteen. After being saved from a shipwreck off the island of Capri, where he lost a good part of his manuscripts, he was appointed historian of the Company of Jesus. He taught in Parma at the Jesuit College, and from 1670 was the rector of the Roman College (Gregorian University). Among his works, the most important is Istoria della Compagnia di Gesu', divided into sections according to geographical criteria, a method still in use in Jesuit historiography.

Carlo Amoretti (Oneglia 1741 - Milan 1816) was a professor of dogmatic theology at the University of Parma in 1767, and of canon law in Pavia (1679). He was also a member of several Italian academies of science. A prolific writer and scholar, he also dealt with art, and agricultural and economic sciences. In 1797, at the Ambrosiana he discovered the Italian manuscript, believed lost, of Antonio Pigafetta on the journey of Ferdinand Magellan, which he published in 1800 in an edition enriched with notes and illustrations. He was the uncle of Maria Pellegrina Amoretti, the third woman to receive a degree in Italy. 


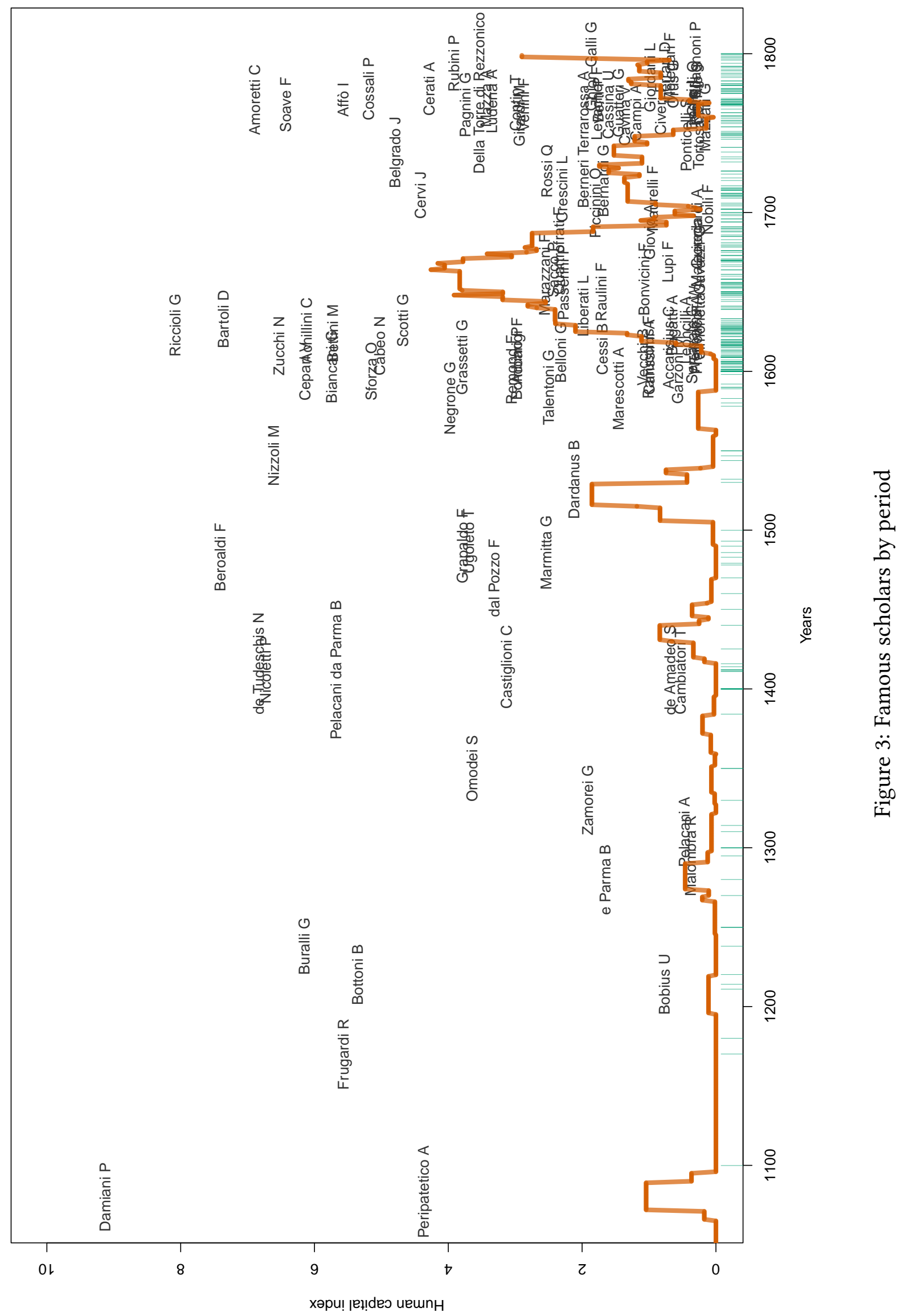




\section{WHO'S WHO ON THE MOON}

Another way to measure the notability of individuals is to look for signs of recognition such as street names, ... and lunar crater names. The following five professors received this honor.

Mario Bettino (Bologna 1582 - Bologna 1657) was a Jesuit, astronomer, mathematician, and philosopher. It was Riccioli himself who dedicated a lunar crater to him in 1651. His main work, The Apiaria Universae Philosophiae Mathematicae (1647-48), is a summa of his studies that includes geometric demonstrations, studies on perpetual motion machines, studies of music, illusionistic stage sets, and anamorphosis.

Giuseppe Biancani (Bologna 1566 - Parma 1624) was a Jesuit, mathematician, and astronomer. Although a friend of Galileo's, Biancani opposed his discoveries on the existence of lunar mountains and the priority given to the discovery of sunspots. The quarrel that arose from these two disagreements put an end to the relationship between Galileo and Jesuit scholars (Grillo 1968). The Italian word "cannocchiale" (telescope) was probably coined by Biancani (Migliorini 1975). The Blancanus crater on the Moon is named after him.

Niccolò Cabeo (Ferrara 1586 - Genoa 1650) was a Jesuit philosopher, theologian, and mathematician. He had a bitter dispute with Galileo. He argued that the mathematician and physicist Baliani had been the first to discover the law of falling bodies. It seems that the idea of the rhythmic rod as an instrument to measure the speed of a fluid current was Cabeo's. The Cabeus crater on the Moon is named after him.

Giovanni Battista Riccioli (Ferrara c. 1598 - Bologna 1671): see above.

Niccolò Zucchi (Parma 1586 - Roma 1670) was a Jesuit, astronomer, and physicist. In 1616, he created the first concave reflector telescope, thanks to which he and his confrere Daniello Bartoli were able to observe the bands in the atmosphere of Jupiter and the spots on the surface of Mars. He is also known to have shown that the light produced by phosphorus was the result of an energetic activation and to have denied the existence of the vacuum. The Zucchius crater on the Moon was named in his honor.

\section{UNIVERSITY NETWORK}

Here, we assume that when a professor occupied a position in more than one university over his/her life, this established a link between those universities. The universities with which Parma is linked are displayed in Figure 4 As can be observed, the professors moved mainly to the nearest universities. In addition, starting in the 17th century, there is a correspondence with the seats of the schools of the Society of Jesus. Once again, the Jesuit network proves to be an important means for the circulation of human capital.

\section{AnecDotes}

The Parma specola (observatory) promoted by Jacopo Belgrado, a Jesuit professor of astronomy and mathematics at the University of Parma, was inaugurated in 1757. It was located in a tower of the College of San Rocco, about 30m high, now the headquarters of the University. It was equipped with numerous instruments, including an astronomical quadrant, made by Parma engineers Stefano Droghi and Pietro Ballarini. It was from there in 1761 that Belgrado determined the geographic position of Parma, to which he gave the values of $44^{\circ} 44^{\prime} 50^{\prime \prime}$ in latitude and $27^{\circ} 35^{\prime} 00^{\prime \prime}$ in longitude, starting from the island of El Hierro in the Canary Islands, used at that time as a reference for the calculation of longitudes (Comi 1997).

The plant genus Guatteria was named after Giovanni Battista Guattieri, a botanist and professor at the university, and the founder of the Parma botanical garden in 1770. 


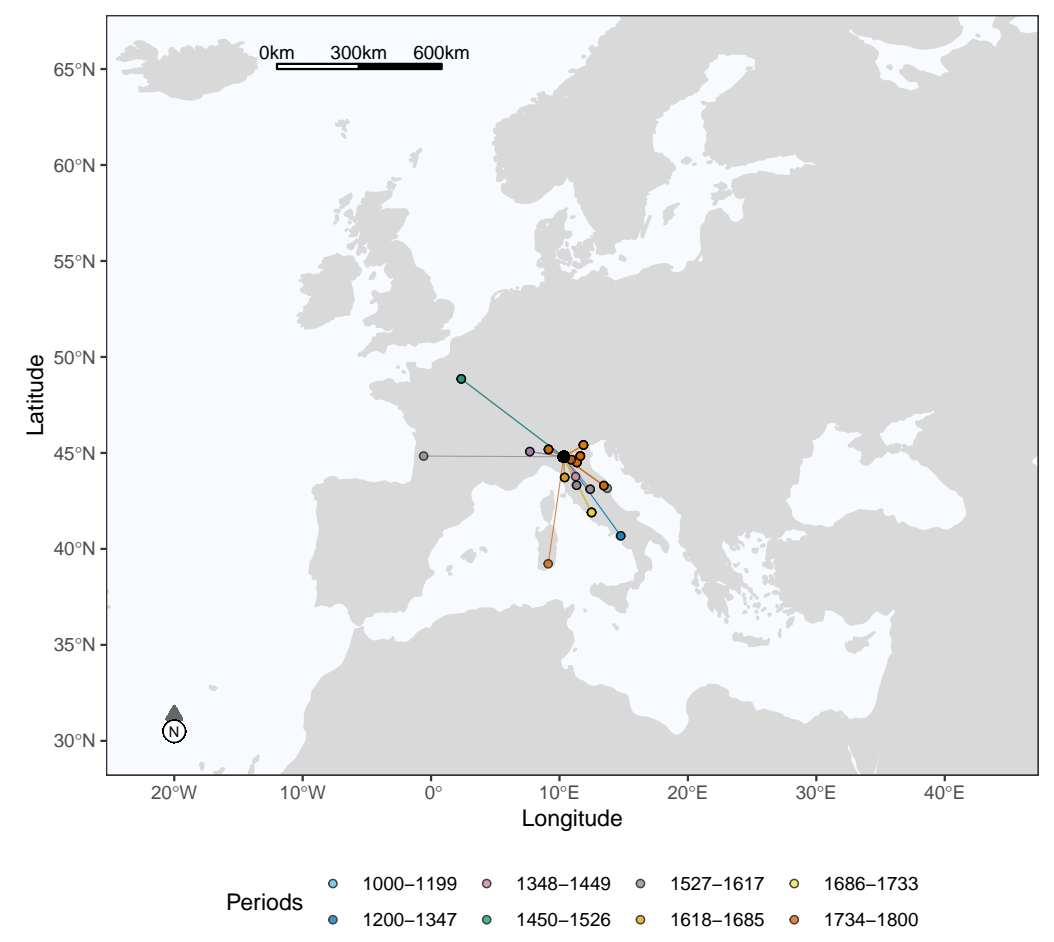

Figure 4: Links between the University of Parma and other universities through scholars' mobility, by period

\section{ACKNOWLEDGMENTS}

This project has received funding from the European Research Council (ERC) under the European Union's Horizon 2020 research and innovation programme under grant agreement No 883033 "Did elite human capital trigger the rise of the West? Insights from a new database of European scholars."

First version December 20, 2021.

\section{REFERENCES}

Comi, Antonio. 1997. Jacopo belgrado e la specola dello studium parmense.

De la Croix, David, and Soraya Karioun. 2021. Scholars and Literati at the Gregorian University in Rome (1551-1773). Repertorium Eruditorum totius Europae 3:19-26. https://doi.org/10.14428/ rete.v3i0/gregorian.

Di Caprio, Giovanni, and Mara Vitale. 2021. Scholars and Literati at the University of Fermo (15851800). Repertorium eruditorum totius Europae 5:27-34. https://doi.org/10.14428/rete.v5i0/fermo.

Frijhoff, Willem. 1996. Patterns. Chap. 2 in A history of the university in europe. vol. ii: universities in early modern europe (1500-1800), edited by Hilde de Ridder-Symoens. Cambridge University Press.

Grendler, Paul F. 2002. The Universities of the Italian Renaissance. Baltimore: JHU Press. https://doi. org $/ 10.2307 / 3738338$.

2017. The fesuits and Italian Universities, 1548-1773. CUA Press. https://doi.org/10.2307/j. ctt1q8jj4h.

Grillo, Enzo. 1968. Biancani giuseppe. Dizionario Biografico degli Italiani 10. 
Istituto dell'Enciclopedia Italiana. 1929. Treccani. enciclopedia italiana di scienze, lettere ed arti. Roma: Istituto dell'Enciclopedia Italiana. https://www.treccani.it/.

Janelli, Giovanni Battista. 1876. Dizionario biografico dei parmigiani illustri o benemeriti nelle scienze, nelle lettere e nelle arti o per altra guisa notevoli per gb janelli tenente colonnello nell'esercito italiano. Tipografia di Gaetano Schenone, Genova.

Mariotti, Giovanni. 1888. Memorie e documenti per la storia della università di parma nel medioevo. 20. A. Forni.

Migliorini, Bruno. 1975. Parole d'autore.

Mrozik Dagmar. 2016. Jesuit science network. http://jesuitscience.net/.

Rizzi, Fortunato. 1953. I professori dell'università di parma attraverso i secoli. Codi.

Sommervogel, Carlos. 1890. Bibliothèque de la Compagnie de Jésus. Brussels: Oscar Schepens. 